\title{
MBOK: ITS DISTRIBUTION, MEANING, AND FUNCTION
}

\author{
Ajar Pradika A. Tur \\ Universitas Gadjah Mada Yogyakarta \\ ajar.ananta@gmail.com
}

\begin{abstract}
Mbok, in Javanese language, has not only a 'mother' in meaning. As a lexicon in the language, mbok in one side truly means a 'mother' and still has the same meaning although it experiences the morphological process to be, at least, embok, simbok, or mboke. The variations exist and are spoken by Javanese native speakers throughout the Javanese dialects such as Suroboyoan, Solo, Yogyakarta, Bagelen, and Banyumasan dialects spread from the East Java, Yogyakarta, and Central Java. However, mbok, as a particle has different meaning, even different various meanings relying on its distribution in a sentence. Then the meanings bear its different various functions as well in the sentence based on the context of the sentence (grammatical-semantics meaning). Through Teknik Balik (Converse Technique) the data gained was analyzed to distinguish the position of the particle in the sentence in order to reach its significant different meanings and functions. At least, from the analysis, we have three positions of mbok in the sentences, that are in the initial, middle, and the end of the sentences. These positions affect the meanings and functions that can be seen as follows; ', is not it?' (Tag Question) and 'is/are" (Verbal Question) for emphasizing, 'please' for requesting a help, 'may be' and 'in case' for expressing possibility, and 'causing' for expressing cause-effect.
\end{abstract}

Keywords: mbok, semantics, Banyumasan dialect

Mbok, in the Javanese language, has a variety of meanings that do not merely mean 'mother'. As a lexicon in the Javanese language, it means 'mother' and has the same meaning despite undergoing a process of morphological lexicon, at least, embok, simbok, and mboke. The lexicons appear and are spoken by speakers from various Javanese dialects such as Suroboyoan, Solo, Yogyakarta, Bagelen, and Banyumasan dialect stretching from East Java, Yogyakarta, and Central Java. But Mbok cannot be interpreted as a 'mother' when is acting as a particle in a sentence.

In Banyumas dialect, lexicon Mbok which acts as a particle has various meanings depending on the attached sentence (grammatical meaning). Particle is a class of words that only has grammatical meaning and does not have lexical meaning (Wedhawati et al., 2006:204). Meanwhile, according to Moeliono (1998:247) particle is a working word which is attached to the word that precedes it. Particle is also a word that usually cannot be derived or inflected containing grammatical meaning but not lexical meaning (Kridalaksana, 2001:155).

In the Javanese language, except Mbok, there are at least 12 single-particle forms, which are kok, dhing, e, i, je, ya, lha, lak, wong, rak, and $t a$. At a glance, they look like affixations, but between the particles and the affixations there are significant differences. As described by Subroto (1991:47) that the particles have the general characteristics of the word class, namely:

1) the membership is limited and closed. That is why the membership must be listed, 
2) particles cannot form the basis or bases for the formation of a further word through morphological process, except in the case of transposition,

3) particles generally do not have a clear meaning at a glance, its meaning commonly becomes clear when is placed in the context of phrases or sentences, and

4) particles are not the center of both, endocentric attributive and exocentric construction phrases.

Through this paper, I was intrigued to analyze the pattern of Mbok distribution in the Banyumasan dialect and expose it. Verhaar (2010) explained that the distribution of particles in a sentence may occur nevertheless it needs to be semantically re-judged whether changing the meaning or not. As the following example:

a) Jono: Apike ngesuk tuku bae, mbok?

It is better to buy, is not it?

b) Joni: Mbok aku tukokna ya!

Please buy it for me!

c) Jono: Ya wes. Tak tulise mbok kelalen.

OK. I write it down in case I forget.

All sentences above contain mbok with various distribution and meanings. The distributions are a) in the end of sentence, $b$ ) in the initial of sentence, and c) in the middle of the sentence. Meanwhile, the various meanings are shown through a) question tag that expresses confirming, b) request that expresses order, and c) possibility that expresses perhaps. As a native speaker, I would like to review how mbok has various distributions and meanings in a sentence depending on the type of sentences. Furthermore, it also has various function in a sentence based on the distribution.

\section{MBOK ANALYSIS}

The particles are a class of words that do not have independent lexical meaning but grammatical meaning which can be identified by its application in the sentence. Thus, the meaning of the particles can vary and depend on the distribution of variation in meaning in the sentence.

\section{Type of Sentences and Mbok Distribution in} the Sentences

Sentence, Frank (1989), is a form of media that is used to convey the message of the speakers. Basically, the form of sentence is declarative and has some decedent forms such as interrogative sentence, imperative sentences, sentences exciting, and so on.

\section{Declarative Sentences}

Declarative sentence is a sentence that contains news or information presented by the speakers.

(1)Jono: Koe arep bali Kebumen kapan?

(When are you going home to Kebumen?)

Joni: Kemis mbok (Thursday maybe)

(2) Mbok koe lolos seleksi beasiswa, lumayan dadi entheng biaya sekolahe. (In case you are qualified for scholarships, it can ease the tuition fees completion)

(3) Bocah ko sinau bae, mbokan pinter. Dolan bae yuh! (You are always studying, becoming a smart boy. Let's play outside!)

Declarative sentence (1) contains mbok that is distributed at the end of a sentence that is used to provide information about possibility. If the particle is moved to the beginning of the sentence, then the particle no longer forms a declarative sentence but interrogative, Kemis mbok to be mbok Kemis? Nonetheless, Kemis Mbok could be an interrogative sentence if the question was answered with the other question but mbok will have different meanings and functions. What happens in the sentence (2) is so in which there is mbok at the beginning of the sentence. It used to provide information, although it is still a possibility, if the particle is moved to the end of the sentence, the sentence will be changed to form interrogative sentences which of course has a meaning and a function that are different. Meanwhile, mbok in the midsentence distribution could basically be realized but the particle gets -an suffix as in sentence (3) which means 'becoming'. 


\section{Interrogative Sentences}

Interrogative sentence is a sentence that is used by speakers to ask questions to obtain information. In question form, mbok has a complete distribution, either at the beginning, middle, or even at the end of the sentence.

(4) Mbok sing arep mangkat sekolah koe? (A the one who will go to school?)

(5) Koe mbok sing mangan apel wingi sore? (You are the one who ate apple yesterday afternoon?)

(6) Lha ya mung koe sing ngerti dalane, mbok? (You know the direction, do not you?)

Sentence (4) is a form of interrogative sentences in which mbok is distributed at the beginning of the sentence. Meanwhile, (5) has mbok in the middle of a sentence and in sentence (6), mbok is at the end of the sentence. Thus, interrogative sentence is a sentence that allows mbok distributed throughout positions, either early, middle, or end of a sentence.

\section{Directive Sentence}

For this kind of sentence, mbok is distributed only at the beginning of the sentence. This can be seen at the examples below:

(7) Mbok gawakna kursine mrene! (Please bring the chair here!)

(8) Mbokaja turu wae kaya enthung! (Please, do not sleep for the whole day like a chrysalis (butterfly metamorphosis phase after caterpillar)!)

Both sentences above, (7) and (8), are containing mbok which is distributed at the beginning of sentences. If mbok is moved to the middle or to the end of the sentences, it forms uncommon sentences, * Gawakna kursine ngene Mbok and *Aja turu bae kaya enthung mbok, it does not have a value in the sentence. Mbok in this sentence could be distributed at the end of the sentence but get suffix -an: Aja turu bae kaya enthung, Mbokan! But it would be different if the particles are getting sufik -an the middle of the sentence becoming Aja mturu bae mbokan kaya enthung! because it changes the meaning of the particle.
From the explanation of mbok distribution above, it can be seen that declarative sentences allow mbok distributed at the beginning and at the end of the sentence. Moreover, for the declarative sentence, mbok could be possibly distributed in the middle but getting suffix. Meanwhile, interrogative sentences allow mbok dispersed in all positions of distribution in the sentence. It is different from interrogative sentences, the directive sentences distribute the particle only in the initial of the sentence.

\section{Meaning of Particles in Sentence}

As described in the mbok distribution above that the distribution has a significant effect in giving or expressing meaning of mbok. The meaning which is born from the presence in the sentence commonly called as the grammatical meaning. Here is a derived meaning of mbok which at least can be found from the various distributions:

\section{Tag Question}

Tag question has the form which is opposite to the main sentence. Frank (1989) also confirms that the assertion truly has no meaning unless the existence of the main sentence accompanies it oppositely. The opposite means that if the main sentence has positive value, so the tag question has the negative one and it is vice versa. For example, in English, there are words "You come late today, do not you?" The main sentence, "You come late today", is considered to be positive so that the shape of tag question should be negative, "do not you". Mbok is possibly to have positive or negative values.

(9) Kancamu kae mahasiswa anyar, mbok? (Your friend is a new student, is not he?)

(10) Bocah kae ora mbajug, mbok? (The boy is not naughty, is he?)

Sentence (9) consists of a main sentence which is considered to be positive and affirming. Due to the main sentence has a positive value, and then the tag question is negative. Meanwhile, the sentence (10) arrangement is vice versa. The 
main sentence is negative, so the tag question is positive. Negative assessment is identified by "not" in the sentence (10).

\section{Verbal Question}

Verbal Question is an interrogative sentence that requires an answer 'yes' or 'no' to the question posed by speakers. This type is basically different from the tag question. It is not confirming or asserting but just asking a question to have answer. The difference is also reflected in the use of the following mbok.

(11) Jono: Mbok koe wingi nggarap tugas nang nggone Hafiz? (Didn't you do the work yesterday at Hafiz's home?)

Joni: Ora kok. (No, I did not.)

However, mbok in verbal question commonly has negative sense to ask a question. It tends to confirm the information of the speaker statement before. It can be identified through omitting the mbok becoming "Koe winggi nggarap tugas nang nggone Hafiz?" It has the positive value. However, if mbok is distributed to the middle of sentence "Koe winginggarap tugas mbok nang nggone Hafiz?" or at the end of the sentence "Koe wingi nggarap tugas nang nggone Hafiz, mbok?", mbok has meaning as what tag question has.

\section{Request 'Please'}

Meaning of 'please' is a representation of the expression of request. In the sense that, speakers want the interlocutors to do what is the speakers want to. In one hand, the meaning of 'please' can be a direct request. But on the other hand, it could mean a command. Mbok makes the command more acceptable and polite.

(12) Mbok adhine gambarna montor mabur sedhela!

(Please, draw a picture of airplane for your brother!

(13) Ngesuk koe sing teka wisudanane Jono mbokan si! (Tomorrow you come to Jono's graduation celebration, please!)

Sentence (12) contains mbok means 'please'. The particle is distributed at the beginning of the sentence although it could also be in the end of the sentence without changing the meaning. However, when the particle is distributed at the end of a sentence, the particle gets suffix -an to keep the meaning in order to avoid the interrogative sentence containing tag question. Sentence (13) is an example of particle formation Mbok + -an. However, if the particle formation, Mbokan, was distributed in middle of the sentence, the meaning changes to 'just in case' which is satire and will be discussed next.

\section{'Maybe'}

Meaning of 'maybe' can be found in declarative sentences containing particle mbok. Judging from its distribution, the meaning can be realized by placing mbok at the end of a sentence like the following.

(15) Mother: Jon, Joni sih mengendi sedina ra keton? (Jon, Where is Joni? I can't see him today.)

Jono: Nang nggone Umar Mbok. Jare latian drama. (At Umar's home, maybe. He said he will rehearse drama.)

Mbok appears at the end of a sentence (15) which is spoken by Jono. Such particle provides 'maybe'. In declarative sentences, Mbok which means 'maybe' can only be found at the end of a sentence. That is because when Mbok is moved to the beginning or middle of a sentence, the meaning is changed into other meanings such as 'just in case' or 'become' by adding the suffix -an to mbok.

\section{'Just in case'}

This meaning is similar to the meaning of 'maybe' but the probability value is smaller than the sense of 'maybe'. That is because the speakers do not have detailed information associated with the object of talking. Thus, speakers use expressions suggestions more frequently because it is assumed more relevant in a high degree of uncertainty.

(16) Mother: Koe ora nggawa payung? (Do not you bring an umbrella?)

Jono: ora lah (no)

Mother: Mbok udan ngko (Just bring it in case it will rain.)

(17) Mother: Kepengen melu meng laut ra koe? Karo bapak kae. (Do you want to join us to go to the beach?) 
Joni: Arep meng kampus bu, ngko awan. (I will go to campus at afternoon, mom.)

Mother: oooh, mbok-embok (Oooh, just in case (you want to go))

Sentence (16) looks Mbok which means suggestions that conveyed by speakers to his interlocutors. The form is a declarative sentence that is distributed at the beginning of the sentence and is followed by another word class. This is in contrast with the sentence (17) which displays Mbok without the presence of other words that accompany it but the particle has reduplication and affix -e. The affix appears maybe because of the effects of Javanese character utterances that put two syllables in one word. For example, a word "ot" which means 'vein' spoken into a "otot" through reduplication basic words. Nevertheless, the meaning of the particles does not necessarily indicate any advice but only gives options such as the possibility of a sentence. The meaning of the particles is not fully suggestion though an expression of the essence of this sentence but is a form of uncertainty.

\section{Possibility 'Might be'}

There is a significant difference in meaning mbok 'might be' with other meaningful Mbok as described above. The difference is the suffix -an attached to the particle.

(18) Kowe manga akeh-akeh, mbokan lemu lho. (You eat a lot, you might be fat then.)

(19) Mbokan nggantheng koe, ngaca bae. (You might be handsome, you dress all the time.)

The use of these particles usually exists in the form of complex sentences to express causation. For example, the sentence (18) informs the causation of eating. Eating a lot, as the effect, is assumed to gain weight or obese as the result. However, we can also see the different meaning of the use of this particle in sentence (19). Those sentences are actually the same in meaning; both are meant as the result but it can be also used as a satire. So that the particle $m b o k+$-an has causal significance of variation in the form of satire and allows to have more variations can be studied through Pragmatics. In addition to meaning, mbok in complex sentences acts as a marker of the clause as a role conjunctions. Sentence (18) for example, consists of a main clause, Kowe manga akeh-akeh, and sub-clause, mbokan lemu lho. So the sentence (19) consists of mbokan nggantheng koe, as the sub-clause and a main clause, ngaca bae. Therefore, bbok $_{+}$-an always appear as a sub-clause in the complex sentences.

\section{Functions of Particles in Sentence}

As mentioned earlier, the mbok in Banyumasan dialect is not merely a lexicon which can be translated into Bahasa Indonesian as 'mother'. However, when examined in depth, Mbok has functions that are closely related to the meaning contained in the sentence.

\section{Expressing Affirmation}

Expression affirmation is related to the meaning of Tag Question or Verbal Question which is brought by Mbok in a sentence.

(20) Wingi bengi Timnas menang lawan Korea, mbok? (Yesterday night National Team of Indonesia won against the Korean national team, did not it?)

(21) Mbok sing ngegolna Evan Dimas? (Evan Dimas scored, did not he?)

Sentence (20) gives the affirmation through a tag question while sentence (21) confirms the information that wants to be known through Tag Question which is in the Indonesian language as a marker of ,kan.

\section{Expressing Commands}

Expression of command containing Mbok contains more polite command than directly stated without mbok. This is quite common in Java people because they prioritize politeness in speaking.

(22) Mbok dibenerna motore ben kepenak! (Please, repair the bike to be better to use!)

(23) Aja berisik bae Mbokan! (Do not be noisy, please!) 
The second sentence is a form of expression of a command through a command expression. However, Mbok which means 'help' soften the expression of both commands and prohibitions.

\section{Expressing Possibility}

This expression has two meaning scopes described above, the meaning of 'possible' and most of the meaning of 'just in case'. Let the following sentence be listened to again.

(15) Mother: Jon, Joni sih mengendi Sedina ra keton? (Jon, where does Joni go the whole day?)

Jono: Nang nggone Umar Mbok. Jare latian drama. (At Umar's home may be. He said they rehearse for theatre.) and

(24) Mbokngesuk langsung dadi, nyong arep meng pejahite siki baelah. (In case tomorrow it will be fixed, I will now have seen the tailor.)

Sentence (15) aboveclearly shows the likelihood function through Mbok which literally means 'possible'. Nevertheless sentence (24) does not directly indicate the meaning function 'may' but rather on the meaning of 'just in case' that has a higher probability. In addition to these examples, see also the sentence (17). The sentence also expresses the possibility through the meaning of 'just in case' which had reduplication.

Expressing Cause and Effect

The last function, at least, which can be found on the mbok is a function of cause-effect expression. This function often appears in a complex or compound sentence that informs causes, which always appears as the main

\section{REFERENCES}

Frank, M. (1989). Modern English. New York: New York University Press.

Kesuma, T.M.J. (2007). Pengantar (Metode) Penelitian Bahasa. Yogyakarta: Penerbit Carasvatibooks.

Kridalaksana, H. (2001). Kamus Linguistik. Yogyakarta: Gramedia Pustaka Utama. clause, and as a result, which is characterized by Mbok as sub-clause. Examples can be seen in sentences (18) and (19). In sentence (18) eating is the cause of being fat while (19) dressing up causes someone becoming good looking, although this is just a satire in Java people.

\section{CONCLUSION}

Mbok in the Java language is a lexicon which means 'mother' but Mbok in Banyumasan dialect is not only the lexicon, but the particle as well. Mbok varies in meaning depending on its distribution in the sentence; whether at the beginning, in the middle or at the end of the sentence. In declarative sentences, which is distributed at the beginning Mbok means 'just in case' with reduplication, Mbok-eMbok, in the middle means 'might be' by affixation of -an, and at the end means 'maybe' and 'might be'. Distribution at the beginning and end of expressing the posibility function while in the middle shows the function of cause-effect. In interrogative sentences, Mbok is distributed in all positions. At the beginning of interrogative sentences, Mbok means verbal question, in the middle of the meaning of 'possible', and at the end of the meaning Tag Question. Well at the beginning, at the middle, and at the end of interrogative sentences, Mbok, serves stated affirmation expression. Meanwhile, in the imperative sentence, Mbok is only distributed at the beginning and at the end of the sentence that means 'please'. But the distribution at the end of a sentence, Mbok get suffix -an. Both distribute functions as a polite command.
Moeliono, A.M. (1998). Tata Bahasa Baku Bahasa Indonesia. Jakarta: Balai Pustaka.

Ritchie, J. \& Jane, L. (2003). Qualitative Research Practice: A Guide for Social Science Students and Researchers. London: SAGE Publications Ltd.

Subroto, E. (1991). Tata Bahasa Baku Deskriptif Bahasa Jawa. Jakarta: Departemen 
Pendidikan dan Kebudayaan.

Verhaar, J.W.M. (2010). Asas-Asas Linguistik

Umum. Yogyakarta: Gadjah Mada University Press.
Wedhawati, W.E., Nurlina, S., Setiyanto, E., \& Sukesti, R. (2006). Tata Bahasa Jawa Mutakhir. Yogyakarta: Kanisius. 
